\title{
Phaeohyphomycotic soft tissue disease caused by Pleurophomopsis lignicola in a kidney transplant patient
}

\author{
C. FARINA, E. PUNITHALIGHAM*, P. RUGGENENTI ${ }^{\dagger}$ and A. GOGLIO \\ Microbiology Institute and ${ }^{\dagger}$ Division of Nephrology, Ospedali Riuniti, Bergamo, Italy and *International \\ Mycological Institute, Egham, Surrey
}

\begin{abstract}
A 44-year-old immunocompromised man presented with multiple tissue abscesses, covering the entire left limb. A dematiaceous fungus compatible with Pleurophomopsis lignicola Petrak was isolated from the diseased tissue in pure culture. This is the second reported isolation of this fungus from man and the first report of fatal soft tissue infection. A detailed morphological description of the isolate is provided.
\end{abstract}

\section{Introduction}

Phaeohyphomycoses are a heterogeneous group of diseases caused by dark pigmented fungi which are common in nature. True human infection caused by dematiaceous fungi in developed countries is uncommon [1]. In recent years reports and descriptions of dematiaceous moulds considered as significant human pathogens causing a range of diseases, including cutaneous, subcutaneous and deep-seated infections have been increasing [2]. This rise can be attributed to the steady increase in the population of immunosuppressed patients. Reports from renal transplant centres experiencing mycotic complications relating to immunosuppression have generally included sporadic localised cutaneous or subcutaneous pathologies and rarely phaeohyphomycosis as defined by Ajello [3].

This is the first reported case of Pleurophomopsis lignicola causing soft tissue infection in an immunosuppressed renal transplant patient. Originally reported from rotting wood in Central Czechoslovakia [4] this newly described human pathogen has also been reported as causing subcutaneous abscesses.

\section{Case report}

A 44-year-old Italian man, an occasional outdoor gardener, underwent renal transplantation for chronic glomerulonephritis 13 years previously. His current

Received 31 July 1996; revised version accepted 10 Jan. 1997.

Corresponding author: Dr C. Farina. medication included azathioprine $150 \mathrm{mg} /$ day, prednisone $250 \mathrm{mg} /$ day and cyclosporine A $175 \mathrm{mg} /$ day.

Two months before admission he developed a purulent lesion on the left forearm and a small mobile lesion on the calf of the leg. Both lesions were aspirated and Staphylococcus aureus and a dematiaceous mould were grown from pus from the arm and leg, respectively. The patient was treated with amoxicillin plus clavulanic acid and the clinicians, alerted to a possible subchronic fungal infection, stopped the azathioprine.

Forty-five days later the patient became febrile (temperature of $38^{\circ} \mathrm{C}$ ) and was admitted to the Nephrology Division, Ospedali Riuniti. Physical examination revealed reddish oedema of the legs and eczematous vesicles on the left arm. Investigations showed anaemia and peripheral leucocytosis (haemoglobin, $8.1 \mathrm{~g} / \mathrm{dl}$; haematocrit, $23.5 \%$; peripheral leucocyte count, $25200 / \mathrm{mm}^{3}$ with neutrophils $87.1 \%$, lymphocytes $4.0 \%$, monocytes $8.1 \%$, platelets $83000 / \mathrm{mm}^{3}$ ) and moderate renal impairment (total serum protein $3.40 \mathrm{~g} / \mathrm{dl}$ with albumin $32.8 \%$ and albumin/protein ratio 0.49 ; BUN $350 \mathrm{mg} / 100 \mathrm{ml}$; serum creatinine $8 \mathrm{mg} / 100 \mathrm{ml}$; SGOT $104 \mathrm{U} / \mathrm{L}$; SGPT $166 \mathrm{U} / \mathrm{L}$ alkaline phosphatase $249 \mathrm{U} / \mathrm{L}$; diuresis $550 \mathrm{cc} / 24 \mathrm{~h}$. A renal biopsy showed tubular damage without signs of acute rejection. Blood cultures were positive for viridans streptococci and penicillin $3 \mathrm{~g}$ three times daily was started. Steroid therapy was stopped and cyclosporine $\mathrm{A}$ was reduced $(100 \mathrm{mg} /$ day). The protein underwent two haemodialysis cycles. A week later the patient was still pyrexial $\left(39^{\circ} \mathrm{C}\right)$. A chest radiograph showed multiple nodular parenchymal opacities in both lung fields. 
Aspergillus fumigatus and Pseudomonas aeruginosa were cultured from broncho-alveolar lavage fluid. Ceftazidime $1 \mathrm{~g}$ twice daily i.v. and itraconazole $300 \mathrm{mg} /$ day were added to the therapeutic schedule but the patient failed to improve. Four days later, physical examination showed a large reddish area on the left leg with multiple soft tissue abscesses and subcutaneous tibiofibular fistulas spontaneously secreting pus.

Direct examination of pus showed rough hyphae with chlamydospores and the culture yielded a dark mould (see below). Itraconazole was changed to amphotericin B $50 \mathrm{mg} /$ day in lipid emulsion (Intralipid $100 \mathrm{ml}$, $20 \%$ ). Pus samples were collected daily and the same dark mould was isolated from four consecutive cultures. The patient became apyrexial and progressively improved on daily amphotericin B. However, 8 days later, the patient presented with acute abdominal pain. An X-ray of the abdomen showed intraperitoneal free air, suggestive of visceral perforation. The patient deteriorated rapidly and died $24 \mathrm{~h}$ later. No autopsy was done.

Microscopic examination of several gram-, Giemsaand haematoxylin and eosin-stained preparations revealed a dense infiltration of polymorphonuclear leucocytes and varying degrees of necrosis and acute inflammation. Several slightly coenocytic brownish hyphae were present (Fig. 1).
No bacteria were isolated but the fungus grew on trypticase soy agar at $35^{\circ} \mathrm{C}$ in an aerobic atmosphere. Mould growth on Sabouraud dextrose agar (SDA) was subfloccose and greyish at 3-6 days, becoming floccose and grey after 6-18 days, with dark pigmentation on the reverse of the colony mat. A subculture of the isolate was sent to the International Mycological Institute (IMI), Egham, on SDA for identification.

On SDA growth was floccose with olivaceous to greyish sepia with abundant aerial mycelium; the reverse of the colony was reddish brown. Mycelium was composed of branched, septate, smooth to roughened to verriculose, yellowish brown to moderate reddish brown hyphae. Conidiomata were pycnidial, solitary or scattered in groups, on the surface of agar, partially immersed, dark reddish brown, lageniform to subglobose, 200-560 $\mu \mathrm{m}$ wide, $350-500 \mu \mathrm{m}$ high, mainly uniloculate, occasionally binoculate with the floor of the cavity sometimes convoluted, with prominent necks beset with flexuous hyphae (not setae), ostiolate (Fig. 2). The pycnidial wall was $20-$ $30 \mu \mathrm{m}$ thick, composed of several cell layers, the outer three-to-five cell layers were heavily pigmented (textura angularis) and thick-walled; the inner layers were thin-walled and hyaline towards the pycnidial cavity. The ostiole was circular, surrounded by thickwalled, dark reddish brown cell layers. Conidiophores were hyaline, cylindrical, septate, branched at the

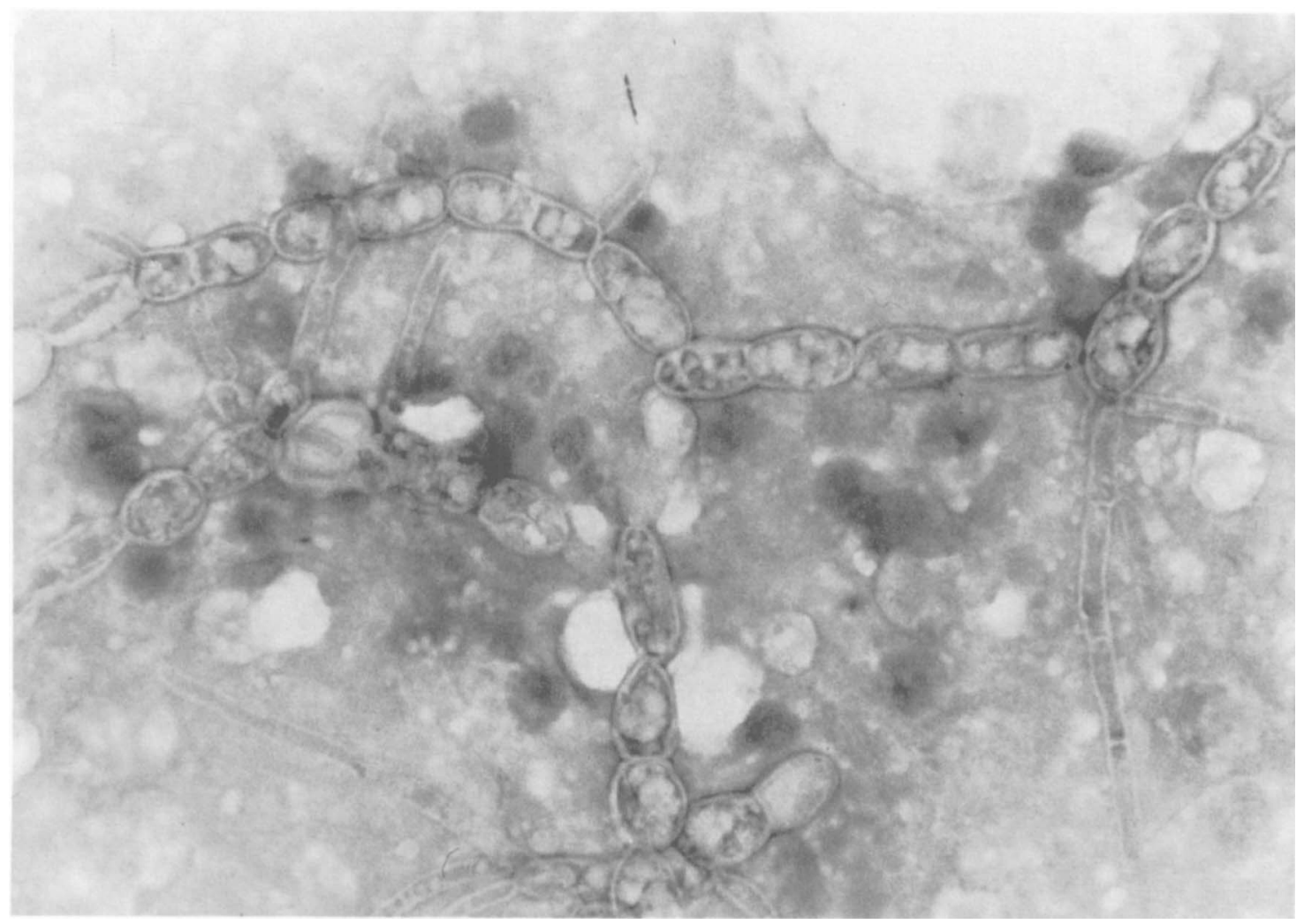

Fig. 1. Infiltration of polymorphonuclear leucocytes and slightly coenocytic brownish hyphae $($ Giemsa $\times 1000)$. 


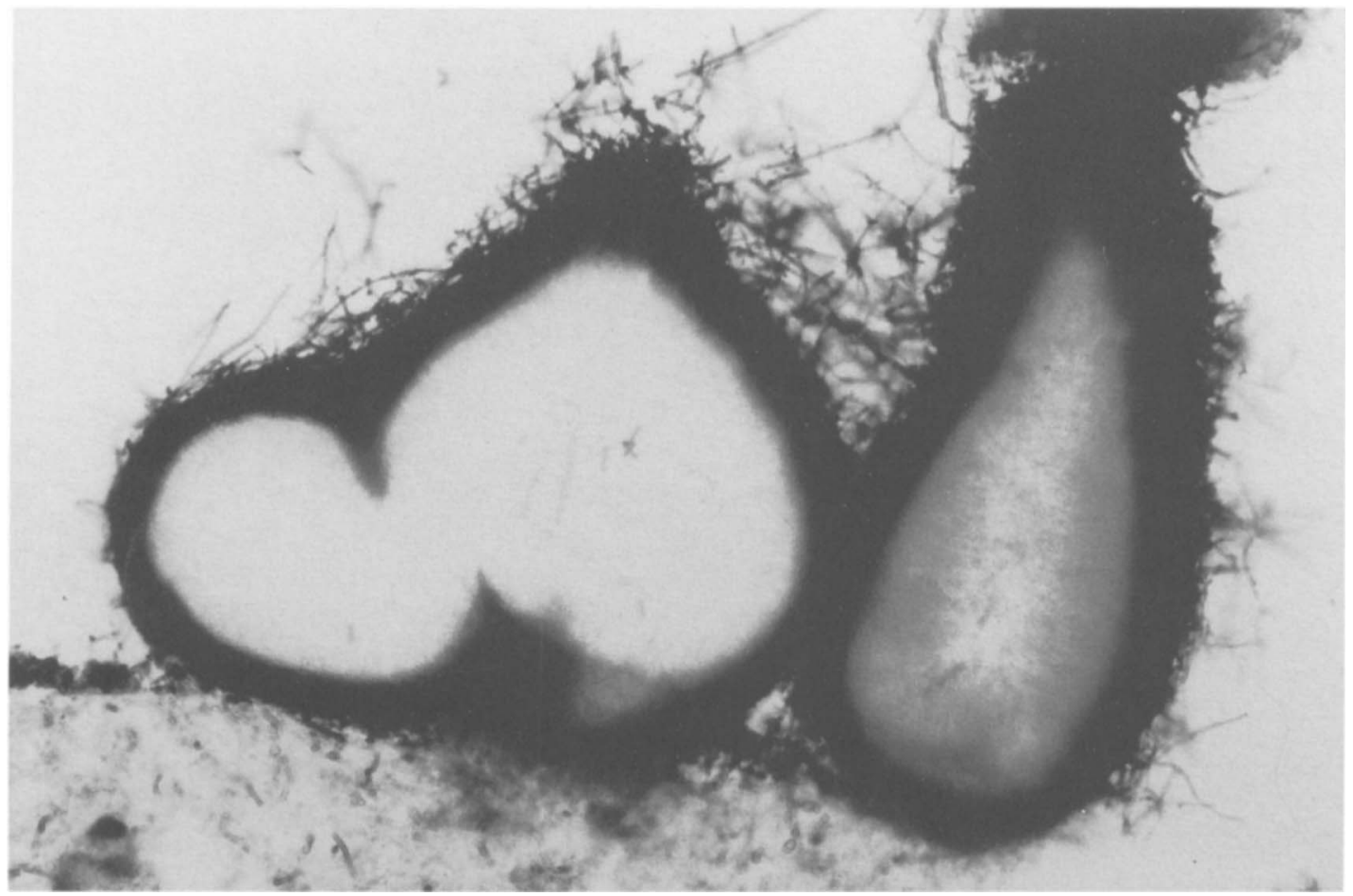

Fig. 2. P. lignicola: vertical section of uniloculate and biloculate pycnidial conidiomata produced on SDA (lactofuchsin stain $\times 164)$.

base, $(25-42) \times 2 \mu \mathrm{m}$, arising from cells lining the floor of the pycnidial cavity (Figs. 3 and 4). Conidiogenous cells, usually borne on conidiophores or occasionally arising directly from the cells lining the pycnidial cavity, were hyaline, cylindrical, smooth, phialidic and acropleurogenous. Conidia were hyaline, shortly cylindrical, aseptate, $(3-3.5) \times 1.5 \mu \mathrm{m}$, guttulate. The isolate matched with the isotype of Pleurophomopsis lignicola Petrak in all essential characteristics. A dried preserved example of this isolate (strain no. IMI 360814) has been placed in the collection of the International Mycological Institute, Egham, Surrey.

\section{Discussion}

Although patient survival 1 year after kidney transplantation is $>90 \%$, infection remains the most important cause of morbidity and mortality. About $70 \%$ of severe bacterial, fungal, and viral complications occur within 3 months of transplantation [5]. Mycotic

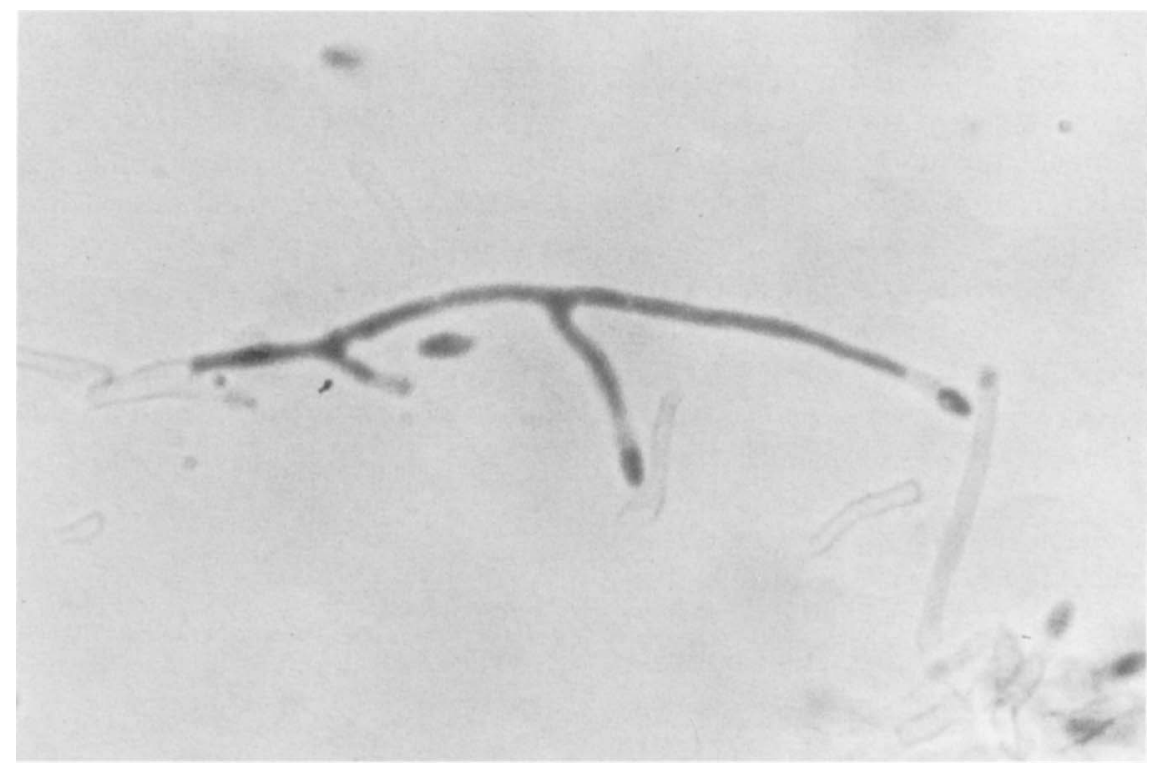

Fig. 3. P. lignicola: unbranched conidiophores (lactofuchsin stain $\times 1300$ ). 


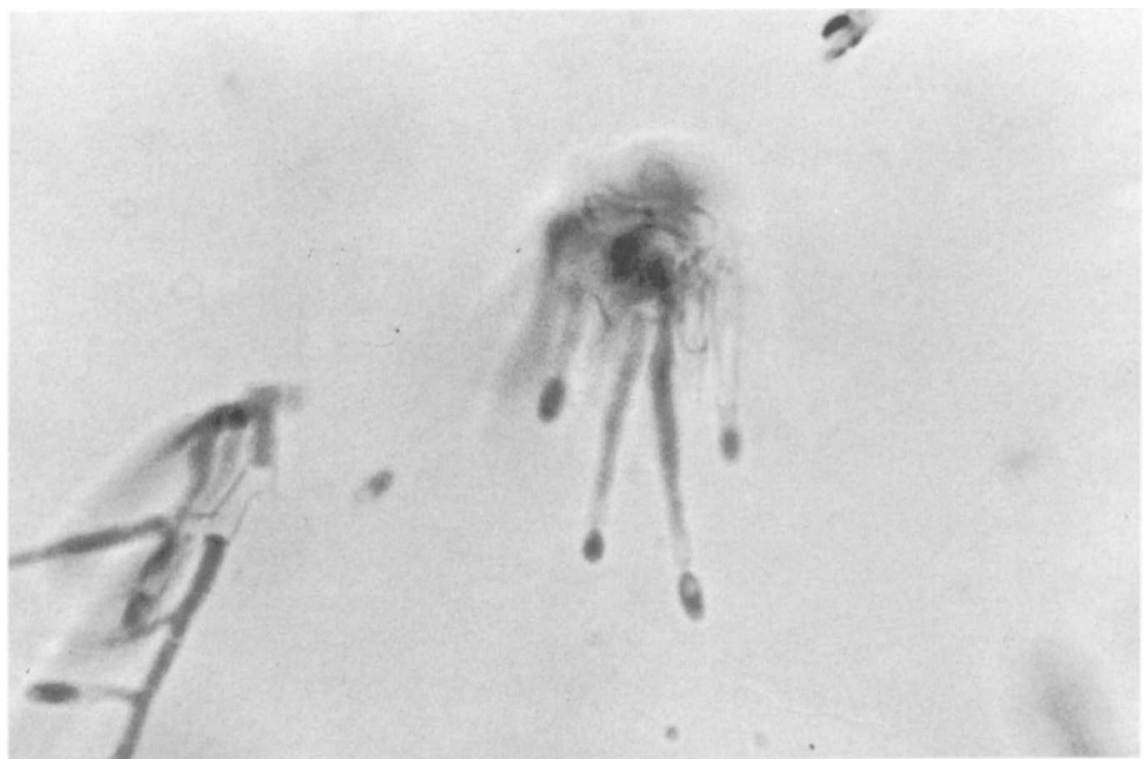

Fig. 4. P. lignicola: branched conidiophores with conidiogenous cells and conidia (lactofuchsin $\operatorname{stain} \times 1320$ ).

complications (especially infections with Candida, Cryptococcus and Aspergillus spp.) account for no more than $5 \%$ of all infections following renal transplantation. However, chronic immunosuppression extends the risk period for several years after transplantation [6]. Among environmental micro-organisms, fungi are less commonly implicated than viruses and bacteria. However, mycotic infection is a more frequent cause of severe morbidity because of the greater difficulties with diagnosis and treatment.

This case report describes a patient who presented with recurrent soft tissue lesions caused by infection with an uncommon darkly pigmented fungus. True human infection with dematiaceous fungi in developed countries is unusual, although case reports in recent years emphasise the pathogenic potential of these moulds. More often chromoblastomycotic agents are described: Alternaria spp. [7], A. alternata [8,9], A. tenuissima [9-11], Exophiala jeanselmei [12], Ulocladium chartarum [13], although in some cases the histological criteria do not permit a definite aetiological identification [14]. In addition, phaeohyphomycoses can sometimes be observed: Bipolaris hawaiiensis [15], Botryomyces caespitosus [16], Chaetomium globosum [17], Chromomycetes [18], Exophiala jeanselmei [19,20], E. spinifera [21], Phialophora parasitica [22], Phialemonium dimorphosporum or P. curvatum and P. obovatum [23].

Pleurophomopsis is a filamentous fungal genus that includes seven species. The isolate described in this case report is compatible with the isotype of $P$. lignicola [24]. The Pleurophomopsis strain described in this patient might be distinguished from typical Phoma species by the production of numerous prominently branched conidiophores which in turn bear conidiogenous cells and conidia and it might be differentiated from true Pyrenochaeta species [25-27] by the absence of setae and the presence of one or two septate conidiophores with one or two branches.

This dematiaceous fungal species has been associated with human pathology before. Within the past 5 years, three isolates of $P$. lignicola from human sources have been submitted to the IMI for identification by workers in France and the USA. Of the two isolates submitted from the USA, one (IMI 354512) was isolated from lung tissue from an immunocompromised patient and another (IMI368308) from human cornea. The French isolate (IMI 366623) was derived from a subcutaneous leg abscess from a 74-year-old farmer undergoing corticosteroid therapy for asthma [28].

The patient in the present study may have acquired his infection through inapparent injury while attending his kitchen garden. Pleurophomopsis species are well known in the rural environment, particularly from plant material, especially from rotting hard wood. However, the environment of the house was not examined for the presence of this mould.

This case of $P$. lignicola infection illustrates the increasing significance of dematiaceous fungi in the immunocompromised population, especially transplant patients on long-term immunosuppression.

\section{References}

1. McGinnis MR. Chromoblastomycosis and phaeohyphomycosis: new concepts, diagnosis, and mycology. $J$ Am Acad Dermatol $1983 ; 8: 1-16$.

2. Matsumoto T, Ajello L, Matsuda T, Szaniszlo PJ, Walsh TJ. Developments in hyalohyphomycosis and phaehyphomycosis. J Med Vet Mycol 1994; 32 Suppl 1: 329-349.

3. Ajello L, Georg LK, Steigbigel RT, Wang CJK. A case of 
phaeohyphomycosis caused by a new species of Phialophora. Mycologia 1974; 66: 490-498.

4. Petrak F. Flora bohemiae et moraviae exsiccata II. serie-1. Abteilung Pilze $\mathrm{Nr} 1680$ (issued 11 August 1923).

5. Paya CV. Fungal infections in solid-organ transplantation. Clin Infect Dis 1993; 16: 677-688.

6. Hibberd PL, Rubin RH. Renal transplantation and related infections. Semin Respir Infect 1993; 8: 216-224.

7. Pedersen NB, Mardh PA, Hallberg T, Jonsson N. Cutaneous alternariosis. Br J Dermatol 1976; 94: 201-209.

8. Bourlond A, Alexandre G. Dermal alternariosis in a kidney transplant recipient. Dermatologica 1984; 168: 152-156.

9. Chevrant-Breton J, Boisseau-Lebreuil M, Fréour E, Guiguen G, Launois B, Guelfi G. [Human cutaneous alternariosis. 3 cases. Review of the literature]. Les alternarioses cutanées humaines: à propos de trois cas. Revue de la literature. Ann Dermatol Venereol 1981; 108: 653-662.

10. Laudren A, Chevrant-Breton J, Pichard JP, Boisseau-Lebreuil MT, Guiguen C. [Cutaneous alternariosis in a patient with a kidney graft: a new case.] Alternariose chez un transplanté rénal: un nouveau cas. Ann Dermatol Venereol 1985; 112: 255-257.

11. Rubio Calvo MC, Marti Lopez J, Gomes Lus R. Granuloma dermico por Alternaria tenuissima en un paciente immunodeprimido. Ponencias 8. Congreso Nacional de Microbiologia, Madrid, 1981: 224.

12. Sindhuphak W, MacDonald E, Head E, Hudson RD. Exophiala jeanselmei infection in a postrenal transplant patient. $J \mathrm{Am}$ Acad Dermatol 1985; 13: 877-881.

13. Blanc C, Lamey B, Lapalu I. Alternariose cutanée chez un transplanté rénal. Bull Soc Fr Myc Méd 1984; 13: 213-216.

14. Morales LA, González ZA, Santiago-Delpin EA. Chromoblastomycosis in a renal transplant patient. Nephron 1985; 40: $238-240$.

15. Koshi G, Anandi V, Kurien M, Kirubakaran MG, Padhye AA, Ajello L. Nasal phaeohyphomycosis caused by Bipolaris hawaiiensis. J Med Vet Mycol 1987; 25: 397-402.

16. Benoldi D, Alinovi A, Polonelli L et al. Botryomyces caespitosus as an agent of cutaneous phaeohyphomycosis. J Med Vet Mycol 1991; 29: 9-13.
17. Anandi V, John TJ, Walter A et al. Cerebral phaeohyphomycosis caused by Chaetomium globosum in a renal transplant recipient. J Clin Microbiol 1989; 27: 2226-2229.

18. Gallis HA, Berman RA, Cate TR, Hamilton JD, Gunnells JC, Stickel DL. Fungal infection following renal transplantation. Arch Intern Med 1975; 135: 1167-1172.

19. Hachisuka H, Matsumoto T, Kusuhara M, Nomura H, Nakano S, Sasai Y. Cutaneous phaeohyphomycosis caused by Exophiala jeanselmei after renal transplantation. Int $J$ Dermatol 1990; 29: 198-200.

20. Sabbaga E, Tedesco-Marchesi LM, Lacaz C da S et al. Feohifomicose subcutanea por Exophiala jeanselmei. Registro de tres casos em transplantados renais. Rev Inst Med Trop Sao Paulo 1994; 36: 175-183.

21. Gold WL, Vellend H, Salit IE et al. Successful treatment of systemic and local infections due to Exophiala species. Clin Infect Dis 1994; 19: 339-341.

22. Fincher RM, Fisher JF, Padhye AA, Ajello L, Steele JC. Subcutaneous phaeohyphomycotic abscess caused by Phialophora parasitica in a renal allograft recipient. J Med Vet Mycol 1988; 26: 311-314.

23. King D, Pasarell L, Dixon DM, McGinnis MR, Merz WG. A phaeohyphomycotic cyst and peritonitis caused by Phialemonium species and a reevaluation of its taxonomy. $J$ Clin Microbiol 1993; 31: 1804-1810.

24. Petrak F. Mycologische Notizen VII. Annales Mycologici 1924; 22: $1-182$.

25. Punithalingam E, English MP. Pyrenochaeta unguis-hominis sp. nov., on human toe-nails. Trans Br Mycol Soc 1975; 64: $539-541$.

26. Schneider R. Die Gattung Pyrenochaeta De Notaris. Mitteilungen aus der Biologischen Bundesanstalt für land- und Forstwirtschaft 1979; 189: 1-73.

27. Sutton BC. The Coelomycetes: fungi, imperfecti with pycidia, acervuli, and stromata. Commonwealth Mycological Institute, Kew. 1980.

28. Chabasse D, de Bièvre C, Legrand E et al. Subcutaneous abscess caused by Plerophomopsis lignicola Petr: first case. $J$ Med Vet Mycol 1995; 33: 415-417. 